\title{
NEGOTIATING DUAL IDENTITIES: A CASE STUDY ON THE NARRATIVES OF TWO MYANMAR REFUGEE YOUTHS LIVING IN MALAYSIA
}

\section{Charity Lee}

Faculty of Languages and Linguistics, University of Malaya, Kuala Lumpur, MALAYSIA

Email: charity.lee@um.edu.my

Published online: 30 October 2020

To cite this article: Charity Lee. 2020. Negotiating dual identities: A case study on the narratives of two Myanmar refugee youths living in Malaysia. Kajian Malaysia 38(2): 61-90. https://doi. org $/ 10.21315 / \mathrm{km} 2020.38 .2 .3$

To link to this article: https://doi.org/10.21315/km2020.38.2.3

\begin{abstract}
This article explores the experiences of two Myanmar refugee youths, who were born and raised in Malaysia - Prince, a Rohingya boy and John, a Burmese boy - through their narratives on belonging and identity and Gee's framework for identity analysis. Selected excerpts from the respondents' narratives were analysed using positioning analysis. A salient aspect in the narratives of both respondents was agency to choose for themselves identities that would enable them to achieve particular goals. The narratives presented here revealed a complex weaving of two main identities: Malaysian and refugee. The analysis revealed how the respondents often chose to downplay aspects of their refugee-ness to take up a Malaysian identity, with both identities functioning as binary identities. However at other times, they also attempted to merge both into a dual or hybrid identity, illustrating that identity work involves overlapping aspects of refugee subjectivities that sometimes contradict each other. The article ends with some recommendations for more inclusive policies for refugees in Malaysia, including crafting legislation that acknowledges refugees and allowing them formal access to learning local languages and integrating with local communities.
\end{abstract}

Keywords: identity, second generation refugees, migration studies, narrative analysis, Malaysia 


\section{INTRODUCTION}

The identities of refugee youth and children remain an under-researched area within migration studies despite often representing a sizable percentage of the total refugee population (Kumsa 2006; Chatty 2007). For example, the United Nations High Commissioner for Refugees (UNHCR) reports some 42,750 refugee children under 18 years old that reside in Malaysia (UNHCR n.d.), which is about a quarter of the total refugee population. Most studies have focused on general populations of forced migrants particularly adults but there have been an increasing number of studies conducted among refugee children and youth that highlight their migratory experiences as well as the positive and negative effects of forced migration on them (Pieloch, McCullough and Marks 2016). To account for the diversity in refugee experiences, second generation refugees have been differentiated in refugee studies from the first generation, i.e., their parents who left their countries of origin as adults (Bloch 2018; Rumbaut 2004; Portes and Zhou 1993). Second generation refugees are born either in a transit or third country and have widely different experiences from the first generation. The first generation were naturally more bound to their countries of origin and retained first hand memories thereof, whereas second generation refugees had more abstract notions of this "home" and relied on the stories of others within their communities (Valentine, Sporton and Nielsen 2009). For those who had the opportunity to visit their parents' country, many reported feeling out of place and foreign (Bloch et al. 2015). In terms of integration, the first generation experienced more cultural and social isolation from the majority communities compared to the second generation, who integrated more successfully especially when given proper educational opportunities (Spicer 2008). The second generation also experienced less overt and non-violent forms of racism in host countries compared to the first generation that included having racialised categories externally forced upon them (Hirsch 2019). Another difference between the first and second generations related to the maintenance of heritage languages, with the second generation retaining higher levels of bi- or multilingualism - both heritage languages and language(s) of the host county - than their parents (Bloch and Hirsch 2017).

Previous studies on identity formation among second generation refugee youth have reported how their identities transitioned towards integration and belonging within their new community. This transition is influenced by several factors. Some studies have looked at broader environmental contexts; one study from the UK found that neighbourhoods composed of residents with similar ethnic or minority backgrounds were considered "inclusive" and refugee children developed more attachment and possibly quicker integration compared to "exclusive" (i.e., majority white) neighbourhoods (Spicer 2008). Other studies have looked at more personal constructs. For example, Sirriyeh (2010) found that 
young women refugees used the concept of "home" to frame their understanding of safety and risk as women in transitory situations, which may not resemble the permanence of home. Another factor is language. One study (Sorgen 2015) posited that refugees, who were acquiring a new language, were better examined from a "new speaker" approach (instead of native vs. non-native categories), which focuses on the speaker's context rather than language mastery. Furthermore, the study explored how their identities related to friendships and found that sense of belonging was shaped through language acquisition. Identity formation for refugee youth can be challenging due to racially-motivated crime from other children (Brahmbhatt et al. 2007) and racism in schools (Hirsch 2019).

Bloch et al. (2015) noted that research among second generation refugees is scarce and following a search of the literature, the author notes that such research has largely been confined to the UK, Europe and North America, such as those mentioned here. Moreover, all the studies mentioned dealt with issues concerning identity and belonging as it applies to integration during resettlement. However, in transit countries such as Malaysia, the refugee can never transition fully into a citizen because of the lack of proper documentation and legal status. As far as the author is aware, there are no studies among second generation refugees in transit countries. This article aims to explore the concepts of belonging and identity of two second generation refugees living in Malaysia through narrative analysis. Research in this area is important because firstly, as the number of refugees in a transit or first country increases, this means a longer processing time, which leads to more refugees and generations of refugees being caught in a liminal place. Secondly, knowing how second generation refugees manage their identities will help case-workers and refugee agencies counsel those caught in similar "inbetween" situations.

\section{REFUGEES IN MALAYSIA: HISTORY, POLICY AND STATUS}

Historically, Malaysia has been home to refugees from the Southeast Asian region for over 40 years starting from the arrival of the Vietnamese refugees during the Indo-China crisis in the 1970s. Myanmar refugees have been seeking refuge in Malaysia for decades, with Muslim Rohingyas fleeing from the north-western Rakhine (Arakan) state in waves since the 1970s, and the Burmese and minority groups fleeing domestic persecution since the late 1990s. Despite this, in terms of official policy, Malaysia is a non-signatory to the 1951 United Nations Refugee Convention Relating to the Status of Refugees, but the state has allowed the UNHCR to process asylum claims and it remains an important destination for asylum seekers. Over the 2012-2015 period, Malaysia consistently ranked as the country with the second highest number of registered asylum claims globally 
(UNHCR 2015). As of August 2018, there are a reported 161,140 asylum seekers and refugees registered with the UNHCR (n.d.) as well as an estimated 200,000 to 300,000 unregistered asylum seekers and refugees, most of them originating from Myanmar. However, annual resettlement rates globally are extremely low due to the stringent selection criterion set by receiving countries, resulting in increasing refugee populations in transit countries such as Malaysia. ${ }^{1}$

In terms of legal status, Malaysian laws distinguish between only two kinds of migrant - "legal" migrants, who have official work permits and "illegal" migrants, who arrive in Malaysia without any documents (Kaur 2007). This has a number of implications for refugees in the country. First, refugees receive some form of unofficial recognition and protection. Despite the lack of legal structures and formal protection for refugees and asylum seekers, those who are officially recognised by the UNHCR receive a basic "de facto status" which recognises them under international law; this allows them limited protection from the enforcement of immigration authorities in Malaysia but no official protection from legislation (Pūras 2015; FIDH-SUARAM 2008). Second, refugees exist alongside other groups of migrants within society. There are no refugee camps in Malaysia unlike those in some other Asian countries, such as Thailand, Bangladesh and India, so refugees live in urban areas alongside other groups of migrants (Crisp, Obi and Umlas 2012). Despite this freedom, this also makes asylum seekers and refugees especially vulnerable to abuse, raids and detention by the authorities (Human Rights Watch 2018). Third, in regard to this study, asylum-seeking children and youth being detained in Malaysia exist in limbo and are unable to access public education (UNESCO 2018). Rohingya children, many of whom are born in Malaysia, continue to live in protracted statelessness and cannot obtain any scholastic qualifications by sitting for state examinations due to their failure to meet the requirements of the government school system (UNESCO 2018). The main excuse given by the government for refusing to recognise refugees has been due to fears that such a move would make Malaysia a main transit point for more refugees (Kaur 2007). The Pakatan Harapan coalition government, which took over from the previous Barisan National government in 2018, campaigned numerous reforms as expressed in their manifesto including promising to ratify the Refugee Convention and give refugees the right to work (Pakatan Harapan 2018), but at the time of writing, had still not announced any decision on this matter (Human Rights Watch 2019).

\section{THEORETICAL CONCEPTS}

This article is guided by several intersecting theoretical concepts, namely identity, belonging and narrative. Identity and belonging are concepts commonly explored 
in migration studies looking at asylum seekers and refugees. Belonging is a concept often linked to migration as it deals with displaced people or diasporas that are not in places or situations regarded as "home" (Wernesjö 2015). They cross geographic boundaries or reside in countries involuntarily and in these new and sometimes hostile environments, struggle to find a sense of belonging in the "borderlands" (Sirriyeh 2010) or liminal non-place (Turner 1967) between origin and host communities. While there are many perspectives to studying the concept of belonging, the post-structuralist view understands belonging as fluid, dynamic and continually negotiated in social interactions and discourses (Sirriyeh 2013; Kraus 2006) instead of tied to a specific and universally acknowledged geographical place. Along these lines, Yuval-Davis (2016) describes belonging as an "emotional attachment, about feeling at home", which also entails the feeling of hope for the future (Hage 1997) and home as a safe space (Ignatieff 2001).

Identity, as an essential component of belonging, is fluid and complex, and the identity of a person cannot be reduced to identification with social groupings or specific macro social categories, such as ethnicity, gender or class (Yuval-Davis $2010 ; 2016)$. Research on the issue of refugee identity, or other frequently used terms, subjectivity or "refugee-ness" (Malkki 1995; 1996), has often been taken to be a universal experience in Western countries as it includes people, who are uprooted and are forced to cross borders (Lacroix 2004). Legal definitions of the refugee further obscure their individual subjective experience and circumstances (Fuglerud 1997) at different moments, e.g., from the point of fleeing to obtaining refugee status and beyond, and at macro (law), meso (policy) and micro (individual social interactions) societal levels (Aberman 2014; Lacroix 2004). The relationship between these levels and refugee identity is dialectical as the refugee cannot be viewed apart from the discourses in which they are embedded (Gass 2014).

Aspects of an individual's identity can also co-exist simultaneously and a useful framework for exploring this is Gee's (2001), which focuses on how different ways to view identity - as nature, institution, discourse and affinity identities are constructed and sustained based on the individual's performances in society. Nature-identity refers to aspects related to one's biological or genetic make-up, e.g., sufferers of genetic diseases. Institution-identities are those given or imposed on individuals by institutional authorities, e.g., nationality, titles, or positions. Discourse-identities are individual traits recognised in the discourse with other individuals, e.g., being friendly or charismatic. Finally, affinity-identities are those taken up by individuals who share common experiences in practices with social groups, e.g., being football fans. Individuals can actively construe and sustain these same identities and/or they can contest or negotiate certain traits based on how they want to be seen.

Narrative analysis, an approach within discourse analysis, views narratives as any text in a "storied form" (Riessman 2005). Narratives allow the speakers to 
present their lives and experiences the way they interpret or "re-imagine" them rather than on actual reality, thus giving researchers an insight to how identities are constructed. Through narratives, speakers do identity work because they tell stories about who they are or are not, as well as who they would like to or should be (Yuval-Davis 2010; 2006). These "identity narratives" provide speakers with a sense of both personal collective order and meaning (Yuval-Davis 2010) as the self-draw boundaries between itself and others in the in-between state of becoming (Bakhtin 1981). The narrated event itself may not always be the focus, instead it allows the speaker to make evaluative comments crucial to doing identity work (Labov 2010).

\section{DATA AND METHOD}

This study uses the positioning analysis perspective within narrative analysis to explore the concepts of belonging and identity of two second generation refugees collected via in-depth individual interviews. Two second generation Malaysianborn Myanmar refugee youths - Prince, a Rohingya boy and John, a Burmese boy (both pseudonyms) were interviewed in 2013 as part of a wider doctorate study on the representation of refugees in Malaysia. In the study, 20 refugees were interviewed and the main criterion for the respondents was that they had to have UNHCR refugee status and have lived in Malaysia for at least three years. Recruitment was done via recommendation by a social worker working with refugee communities and respondents were interviewed after providing informed consent. The interviews were very open-ended and started off with "grand tour" questions (Spradley 1979) aimed at eliciting narratives about how the respondents became refugees, followed by questions to elicit narratives about living in Malaysia.

These two respondents were selected for this article because both respondents were the only minors that participated in the study. Although the researcher was initially looking to recruit only adult refugees, both youths showed interest and requested to participate. The interview structure was adapted for them to account for their second generation experiences regarding their life and relationships in Malaysia. Interviews were conducted in English with instances of switching between English and Malay by both the interviewer and the youths. Both interviews were transcribed into English using the basic transcription conventions by Jefferson $(1984 ; 2004)$ with back-translation into English for the Malay and bi-lingual portions (refer Appendix). In the excerpts quoted in this article, the interlocutors are the researcher (R), Prince (P) and John (J). The respondents' narratives were coded using the qualitative software, NVivo 10 for salient themes and analysed using the positioning analysis perspective (Bamberg 1997; 2003; 2004b). 
"Positions" are "identity-relevant effects of the way speakers order conversational devices and discursive activities" (Korobov and Bamberg 2007, 256), which emerge during the course of a performance of a narrative or its delivery. The focus on positioning is useful for understanding not only how identities are created but also how speakers take up existing ones through "narrating-ininteraction" (Bamberg 2004a) vis-à-vis master or meta narratives. Hatoss (2012) advocated the use of positioning as an appropriate analytical concept in the study of identity in narrative because it aims to capture both the narrated event (the story) as well as the narrating event (the interview). This approach was suitable for this study to account for the undeniable influence of the researcher during the interviews in co-constructing the narratives with the respondents instead of treating the interviews as existing in a transparent context (Atkinson and Delamont 2006). The study took the view posited by De Fina (2011) that storytelling are shaped by the relations and interaction of all participants. Furthermore, storytelling becomes the site for identity construction and negotiation as participants inevitably positioned themselves in particular ways vis-à-vis the researcher (De Fina 2011). Because the research setting shaped the data collected, researcher's neutrality or the Observer's Paradox was unlikely to have been achieved. To accommodate this situation and the view of identity as dynamic and dialectical, the researcher decided on positioning analysis to include and account for her presence in the research interview and the excerpts presented reflect this.

Positioning analysis involves a three-step analysis. At positioning level 1 (story level), the characters mentioned in the narrative are identified, particularly as described by the narrator. The analysis looks at nouns, adjectives and phrases used to describe characters and also how these characters are voiced through direct or indirect quotations. Positioning level 2 (interactional level) involves focusing on how identities emerge through the interaction between the participants involved in the "telling" of the story in the questions and answers as part of "turn-taking" (Sacks, Schegloff and Jefferson 1974). Integral to this level is whose perspective becomes the point of focus and how these exchanges shape the overall narrative. The final positioning level 3 brings both the previous levels together by examining the recurring references to specific meta-discourses that narrators use to establish their sense of "Self" and justify this representation of themselves. As speakers create "a sense of (them as) selves" that is embedded into the story and interaction levels, this leads to the question, "Who am I?" (Bamberg 2004a, 336). It is only when speakers have established "subject positions" that they can go on to develop a sense of continuity and Self. Gee's framework of aspects of identity was applied in this final level of analysis as an analytical tool to identify which aspects of identity was involved in the research interaction. These identities were categorised under the four aspects: nature, institutional, discourse and affinity. Those identities were then grouped into larger thematic identities, referred here as "main identities". 
It is important to note that the analysis process was not always linear, with each positioning level informing the others through numerous rounds of analysis.

The limitations of this article also need to be acknowledged, namely, that it is a case study of only two out of the 20 respondents of the study. As such, it is important to recognise that the findings are not representative and the conclusions cannot be generalised.

\section{FINDINGS}

A salient aspect in the narratives of both respondents was agency to choose for themselves identities that would enable them to achieve particular goals. Two main identities emerge in the narratives presented here: Malaysian and refugee. However, as will be demonstrated in this section, both these identities should not be viewed as separate as they frequently overlap and intersect. At times, respondents either actively take up or resist a particular identity for practical reasons and make certain aspects of the identity visible or invisible. At other times, they took up more dual or hybrid constructions of identity.

\section{Belonging to Malaysian or Refugee Identities}

For many refugees, regardless of whether they are in transit or in third (i.e., resettlement) countries, one of the biggest challenges is negotiating the change in their identity from citizen to non-citizen outsider. This process is more unique and complex for second generation refugees, who have no country of origin as their parents did, and they struggle to choose between either their ethnic or host country identity. For Prince and John, taking up the Malaysian (i.e., host country) identity or the emphasis on their "Malaysianness" were strategic and intentional moves to attain a sense of belonging. This belonging was not expressed patriotically, but rather for practical reasons to avoid potential unpleasantness that may come with the refugee identity. In the following excerpt, Prince explains that he often passed for a Malaysian to avoid awkward, probing questions to make his "life easier" by not having to talk about his refugee status. 


\section{Excerpt 1}

1 R: Let's talk a bit about, about living in Malaysia like uh, would you consider yourself Malaysian? Any part of you? (.) Like you know, you would say this is my home.

2 P: Yea, I do consider myself as a Malaysian.

3 I mean even if I don't say myself as Malaysian then I'll be recognised as a refugee.

4 And if they ask why, what is a refugee? I hate to answer that question.

5 Because I have to go in detail, what is refugee, where did they came from, what is this, what is that? UNHCR...

6 I have to explain all these kind of things, so to make my life easy and the person life easier, I just said "Malaysian".

7 They won't ask me any more questions. Boom. Finish. Easier.

8 R: So, what is that, being a Malaysian to you?

9 P: What do you mean?

10 R: I mean, if you say you're a Malaysian, what is a Malaysian? What makes a Malaysian a Malaysian?

11 P: Um, well, I go, I sing the=

12 R: =You speak BM or what?

13 P: I speak BM, I sing the NegaraKu (national anthem) every Monday at assembly

14 and $\mathrm{uh}$ (.) I respect the people here and gov= I mean, not really the government actually, the laws, yes.

In this excerpt, the researcher asked Prince if he considered himself Malaysian and "at home" here. Prince responds by identifying two identity options in his narrative, the Malaysian and the refugee (lines 2-3). Both these identities are institutional ones and, in this instance, presented as binary identities. If he does not take up the Malaysian identity, he will be recognised as a refugee (line 3) by a generalised third party ("they"). The refugee identity here comes with legal and institutional baggage (line 5) and something Prince preferred to avoid. When probed about what "Malaysian" meant to him (line 8), Prince and the researcher collaboratively listed down patriotic practices associated with the affinity-identity that Malaysian citizens would typically have (lines 11-14), drawing on their knowledge of the defining ways Malaysian citizens showed patriotism, i.e., by singing the national anthem (Ting 2016; 2017) and speaking the national language (Phan, Kho and 


\section{Charity Lee}

Chng 2013). Likewise, John also made the connection between belonging and living life without "too many hindrances":

Belonging means to me to be able to perform little everyday tasks you know, just to be able to enjoy the things that in a particular place without too many hindrances. And to be able to identify with the people and the environment.

The ability to assimilate successfully into the local community was an important theme in both respondents' narratives and for Prince, the key to achieving that was in assuming a public Malaysian identity. He discussed this through the description of hypothetical situations in Excerpts 2 and 3.

\section{Excerpt 2}

1 P: People here very warm, very nice. Yeah, they're very nice.

2 It's just some people, some obviously like the minority of the...

3 will assume we are just um, like people who are staying here without, aimless, I mean like chicken with no heads. ((laughs))

4 They - I don't know how to, how to really describe us.

5 But they don't look us in a positive way. Yeah, they don't look at us in a good way.

6 R: So, you don't feel part of the Malaysian community at all lah?

7 P: No. Not really.

8 R: Unless you put on your fake self, right?=

9 P: =Yeah. [Then, yeah

10 R: [Then,

11 P: They'll like, they'll like accept me.

12 R: So, if you, one day you go out and you say, 'Yeah, actually I'm Indian', so then you feel Malaysian?

13 More, [treated like a Malaysian?

14 P: [Yeah, kinda. Yeah, they treat me differently actually.

The story world character "people" or "they" here referred to Malaysians, who were presented through Prince's eyes as narrator as identifying refugees negatively with the discourse-identity of "headless chickens" (line 3 ) and outsiders. The "fake self" (line 8) and "Indian" (line 12) are performed affinity-identities suggested by the researcher as alternatives, with the latter alluding to the fact that Rohingyas 
and Indian Malaysians both have similar dark-skin and features. Prince agreed that if he took them up, he would not be discriminated against, reflecting the hegemonic racialisation that Rohingyas continue to face in Malaysia (Avyanthi 2014; Hoffstaedter 2017). His narrative on racial discrimination continues into Excerpt 3.

\section{Excerpt 3}

1 P: Yeah, actually that's how it works. When you hide your true identity, they'll be like so different to you.

2 R: When you say different, what do you mean? Besides the look and the things they say about you or to you, what [else?

3 P: [They will say that, okay, first they will say,

4 if I say I am a Rohingya, then they will say, they will never, not ever, ever say good thing about Rohingya.

$5 \quad$ They will say, 'You know, last week ah what happened in the duhduh-duh-dah, in this place,

6 you know I saw in news, you know the Rohingya people, they've been doing this nonsense, this and that.'

7 'Oh! Yeah. You are right.' I just say like, 'Oh yeah, mmm okay. (.) Oh, I see.'

8 That's how my reaction and I try to avoid them and try to go away

9 and they keep the conversation on and on and (.) it goes on my head. I just can't do anything.

Prince alluded to the Rohingya identity here as his "true identity" and one that he wanted to conceal in social interactions because it was a negative affinity-identity prescribed by "they" (Malaysians). In bringing up this hypothetical situation, he drew on larger media discourses (line 6 "I saw in the news") that have represented refugees as problematic and responsible for social ills (Hoffstaedter 2017; Zuraidah and Lee 2014).

In contrast, John spoke about his Malaysian identity as something quite natural, describing himself as "more Malaysian" than other Malaysian school friends because he spoke like a Malaysian, demonstrated here in Excerpt 4. 


\section{Excerpt 4}

1 R: So, how much of Myanmar culture do you retain in terms of maybe festivals, food... anything?

2 J: I think the only thing I retain is food.

3 Apart from that, from my music that I listen to, from the- way I dress to the way I... talk...

4 to my perception of... everything I guess I'm more Malaysian than... than Myanmar.

5 R: OK. [So then-]

6 J: [In FACT I think] I'm more Malaysian than some people in my school. (I laughs)

7 Like... for example, like in terms of speaking Malay right...

8 my class particularly, there's this one guy who... has been to international (school) his whole life... his whole life just been in Jaya (international school) for his whole life...

9 so... when he speaks Malay right... he speaks as if it was written.

10 Like, <'Saya mau beli... > ((laughs)) goreng pisang' (I want to buy fried banana)

11 like- he will speak with- yea... [it's just weird]

12 R: [Like a...] child lah or learning to read, right?

13 J: And I would say I'm better than him in Malay definitely.

In Excerpt 4, the researcher brought up the topic of Myanmar culture as an affinityidentity but John only took up one aspect relating to this culture, the food (line 2). He then positioned himself prescribing to more aspects of the Malaysian identity (lines 3-4) including speaking Malay and illustrated this point with a story comparing him with his Malaysian classmate. Drawing on the discourse that all Malaysian citizens should be able to converse in the national language, he uses this to legitimise his claim that he is Malaysian. He compared himself to someone who was a Malaysian citizen, but yet did not exhibit the quality of being able to speak the national language. The implication here is that nationality alone may not be enough for someone to qualify as truly "Malaysian" and that there somehow appears to be degrees of "Malaysianness" that speaker can appropriate.

Despite repeatedly emphasising their "Malaysianness", both respondents also frequently took up the identity of the refugee, especially when describing the struggles faced both in Malaysia and in Myanmar. While speaking about the plight 
of the Rohingyas, Prince used the pronoun "we" to include himself into the larger Rohingya community:

But here, can do a job, even though it's kind of illegal, it is illegal for us, for Rohingyas to do job. But that is the only way for us to survive, I mean what else can we do? I mean we cannot indulge in robbery and those kind of criminal thing [sic]. So, even though it's illegal, to support ourselves, our family, we have to do this, we have do a job even though it's illegal.

This "illegal" representation of the Rohingya identity acknowledged the institutionidentity imposed on refugees by the government but he provided justification for Rohingyas working due to having no choice. Indeed, he implied that working illegally was better than participating in illegal activities.

However, as can be seen in Excerpt 5, Prince's knowledge of the Rohingyas in Myanmar is second-hand knowledge based on things he has seen in pictures and what his parents have told him.

\section{Excerpt 5}

1 R: So, I mean, you have, do you have any emotions about your home country?

2 P: I do have an emotion, I do, I do have.

3 When I see the pictures, people who are staying, Rohingyas who are still staying there,

4 compared to myself and them, they're really in need. They really need help.

5 It really a shattering experience when you see those kids over there,

6 running around naked, some of them having all sort of diseases and stuff.

$7 \quad$ My own people, Rohingya, over there.

8 R: Um, do your parents tell you anything, any stories about Myanmar?

9 P: Wait, let me remember.

10 R: Cultural stuff, anything.

11 P: Cultural... not really.

12 But they, but they always tell that people over there are terrorised, they're being killed, they're being slaughtered.

13 And when they try to escape, they like... bombed. 
14 So yeah, most of them is like more of, more on violence, which I don't really listen to those things.

15 Sometimes I have to listen because they're saying in front of me and I can't close my ears and yea, try to not listen, I try not to listen to them but I have no choice.

When asked about his feelings about his home country, Prince talked exclusively about the Rohingyas in the third person ("they") as being victims of the violence in Myanmar and a discourse-identity that is separate from his own. The Rohingya identity that Prince supposedly embraced then becomes somewhat problematic. The description he provided about them was based on pictures he had seen of diseased and naked children (line 6), which is consistent with the visual representations common in discourse among humanitarian agencies of the refugee as a mute and helpless victim (Rajaram 2002; Johnson 2011), as well as "heritage narratives" (De Fina 2008) about the violence in Myanmar relayed to him by his parents. In this view, the refugee is a victim of violence and is most often represented by a woman or a child. Prince did not have any actual personal experience of the Rohingyas with which to form his own opinion and understanding.

John admitted not revealing his refugee identity to people he met from the start but stressed that he did not conceal it when the conversation demanded it. $\mathrm{He}$ explained that unlike other refugees, he appeared Malaysian to other Malaysians and therefore, had the reverse experience of having to convince people that he was a refugee, not a Malaysian citizen.

\section{Excerpt 6}

1 Personally for me particularly right, the first time they see me... they see me as a Malaysian.

2 So, I don't have to play that role you know.

3 It's like, they see me... I think I'm the opposite to the people that you've actually met

4 'cause those people they... people don't see them as Malaysians.

5 But for me they see me as Malaysian but because I'm NOT, I have to change the way they think about me.

6 So that they know that I'm uh... I'm culturally Malaysian but not Malaysian like fundamentally and just... yea.

In this narrative, John presented himself as possessing the discourse-identity of a Malaysian, as positioned and recognised by the generalised third person 
("they"), who he claimed came to this conclusion when they met him (line 1), and not something he intentionally performed (line 2 ). In line 3 , he stepped out of the narrative to speak to the researcher and assert that he was different from other refugees he had met because other Malaysians would not identify him as a Malaysian. This narrative that his Malaysianness was validated by others further strengthened his claim that he was culturally Malaysian (affinity-identity), although not one "fundamentally" (institution-identity).

\section{Dual and Multiple Identities}

At times, identity was not presented as binary but a hybrid of sorts, consisting of refugee and Malaysian. Because such a category was non-existent, Prince coined his own term for this dual identity - "Rohingya Malaysian".

\section{Excerpt 7}

1 R: Yea, let's say in Malaysia, what would be a [perfect day?

2 P: [Oh, in Malaysia.

3 Um... (.) Okay, for us would be (.) I get my IC and I see all my siblings studying in a very, very good school.

$4 \quad$ Probably Chinese school, I want them to study in a Chinese school because I feel like Chinese schools are the best schools in Malaysia. Okay?

5 Um, I see my parents, they are no more working hard, not really. They have their own business, which they got boys working under them.

6 Um (.) for me, I (.) I'm recognised and even though I'm a Rohingya, people recognise me um (.) Rohingya Malaysian.

7 And people respects [sic] me because who I am.

The researcher's question on the perfect hypothetical day was used by Prince to not only speak about his hopes for his family members but also himself. While his hopes for his family entailed acquiring objectified cultural capital, which involved academic opportunities and financial stability, his hope for himself centred around institutional cultural capital, i.e., legitimacy through a new status - a Rohingya Malaysian. Prince explained the reason for choosing this dual identity. 


\section{Excerpt 8}

1 R: [So, if let's say one day you got permanent, you got Malaysian citizenship, would you still prefer to be called Malaysian or Rohingya?

2 [If let's say you

3 P: [Rohingya Malaysian.

4 R: Okay, why with the Rohingya?

5 P: Because I, I don't want them to know like my half identity, you know.

6 When I say I'm Malaysian, I'm like half. It's like not complete.

7 I'm hiding the other half of myself.

8 When I say the other half, then they will ask, 'Then what is Rohingya?' This and that.

9 Then I don't know what to answer.

10 But once I get like Malaysian, like real citizen, then I can say Rohingya.

11 I'm not sure whether I will really become citizen here or not.

12 So, how if I say I'm Rohingya and then later oh, I don't have it.

13 I mean, I'm Malaysian now then when I say later, I don't have an IC, then what would it be? I'll be back to where I was=

14 R: =So, this IC was given by who? The government?

15 And then they say that you can only have it till 2014?

16 P: Um, yea.

17 R: And then, you don't know what happens after that?

18 P: Mm hmm. ((nods))

The reason Prince provided for taking up this new dual identity was because merely taking up either the Malaysian or the Rohingya identity would mean that he was "hiding" part of himself or existing as "half" a person (lines 5-7). In reality, this identity is not a viable or valid identity as Rohingyas have not been legally recognised as citizens in Myanmar or Bangladesh, who have both been trying to push them back into each other's territories for years, ${ }^{2}$ and are merely given permission for temporary stay in Malaysia.

From line 10, beginning with the interviewer's question, both the researcher and Prince played out a hypothetical situation, in which he could choose his identity freely. He rejected the choice to "hide" half of his identity as either, (a) Malaysian with no Rohingya identity, or (b) a Rohingya that existed as an 
illegal/non-Malaysian. In line 18, "they", presumably Malaysians, were voiced asking him to explain what a Rohingya was and here, Prince's response, "Then I don't know what to answer", alluded to the conflicting meta-narratives on and uncertainty surrounding the identity and origins of the Rohingya people (Imtiaz 2009). Prince then moved the focus onto the subject of citizenship and the temporary identification card (IC), explaining that he would only feel comfortable publicly calling himself a Rohingya if he secured Malaysian citizenship. Prince returned to the subject of citizenship and the IC numerous times during his interview, discussing his parents' protracted stay in Malaysia without any sign of obtaining citizenship at length and expressing the frustration he felt at being stuck in this stateless situation. This lack of access to institutionalised cultural capital explains Prince's reliance on linguistic and cultural knowledge to secure cultural capital.

Prince and John frequently made references to the fact that they were born in Malaysia and thus, know the local language and culture. Thus, culture and language, particularly the Malay language, were an important part of their local identity. John reinforced his "born in Malaysia" identity by telling stories about his interactions with his local friends and the use of Malay and knowledge of local idiomatic expressions and cultural references as can be seen in Excerpt 9.

\section{Excerpt 9}

1 R: How about the word 'identity', what do you think that means?

2 J: Uh... to me ((laughs)) identity? Mm... it means to... it's very hard for $m e=$

3 R: =Or what is your identity... if you were to-

4 J: Um... I would say... I mean if someone asked me where... where I'm from, I would say I was born in Malaysia... but my parents are Myanmar. That's what I would say.

5 R: You would never say, 'I'm from Myanmar', right?

6 J: I will always emphasise I was born in Malaysia. My parents from Myanmar.

7 Yea that- Malaysia part I would really emphasise because... it would give them the wrong idea lah I mean from Myanmar- if you say asI'm from Myanmar.

8 Then they'll be like, 'Ohh... so.... do you... ((laughs)) Do you know nasi lemak, do you know teh tarik?'

$9 \quad$ Like- 'Yes, I know these stuff you know.'

10 I even had once- I had a friend... when I was in Year 10, he was new to the school... 
11 and we were in the canteen eating together.

12 I was there for Jaya International (pseudonym) for more than one year already and...

13 Waiting in the canteen and then... one day this guy asked me, 'Eh John, do you know this Chinese uh... this dish called $<$ bak... kut... teh?' ((R laughs))

14 Then I just looked at him and I'm like... ((laughs)) 'YES.' ((laughs))

15 And he realised, 'Oh you actually- you're familiar with it?'

16 Then he just laughed and then... he embarrassed himself lah so...

In this exchange about what identity meant to John, the researcher started asking if his identity was linked to Myanmar and John emphasised strongly that Myanmar was his parents' country of origin. The construction of the "born in Malaysia" but "my parents are from Myanmar" identity (line 4) allowed John to merge these two identities into one. Place of birth and the jus soli principle, i.e., the right to citizenship based on place of birth, seem to be particularly important in his identity claim as a Malaysian because Malaysia is the preferred location, not Myanmar. This is referred to as "place identity", which can be defined as the process, by which "people describe themselves in terms of belonging to a specific place" (Hernandez et al. 2007, 311). The story he then told about his friend was told to illustrate that his knowledge of local cuisine allowed him to reinforce his Malaysianness and resist being positioned as a foreigner.

The ability to speak multiple languages was identified by Prince as a skill he picked up in Malaysia that helped him fit in with other social groups. In this case, he took up multiple identities based on convenience and who he was interacting with; "camouflaging" as he described it in Excerpt 10.

\section{Excerpt 10}

1 Whereas, sometimes I say I'm Punjabi and they like, because I can speak six languages,

2 so it's not a big deal for me to say I'm Malay.

3 When I'm say Malay, I speak Malay. When I'm Indian, I can speak=

4 R: =Tamil?

5 P: A bit of Tamil. So, when I say I'm Punjabi, I can speak Punjabi. And sometimes I say I'm Pakistani.

6 ((I laughs)) Yeah, I can speak Hindi. So I like, I interact in Hindi.

$7 \quad$ Actually mostly I say [I'm Pakistani. 
8 R: [Learn yourself or just interact with your friends?

9 P: Um, I learn from my, uh watching movies. I interact with my friends.

10 So, when I'm with my friends, actually when I'm with my Pakistani friends, when they ask me where am I from, I say I'm Pakistani too. I'm also a Pakistani.

11 So I speak in their language.

12 So they won't like, I just camouflage, I just camouflage with them.

Analysis of the narratives of both respondents showed that linguistic skills and cultural practices were used as the main means of attaining "cultural capital" (Bourdieu 1986; 2004), which is expressed through an understanding of the dominant culture in a particular society. This understanding includes a variety of cultural elements such as languages, accents, credentials, mannerisms, clothing and so on, which can be attained through association with a particular social class or social group. Cultural capital is desirable as it enables an individual to attain acceptance into a particular collective identity and a sense of belonging. Bourdieu identified three forms of cultural capital - embodied (inherited traits), objectified (physical and material possessions) and institutionalised (credentials, titles, status) - which would allow an individual to succeed in society.

\section{DISCUSSION}

This study shows that the dual identities negotiated by the two refugee youths involve a number of complications and tensions. Previous studies have also reported that tensions between belonging vs. exclusion, and old ethnic vs. new national cultures, are common among youth and second-generation refugees and migrants (Chatty 2007; Portes and Zhou 1993; Jodeyr 2003). What is unique in this study is that Malaysia's lack of legal refugee status generates a tension between not having a Malaysian institutional identity yet requiring one to operate in society. While both youths acknowledged their refugee identity, both also mentioned that they needed to convince others that they were Malaysian by taking advantage of their similar physical characteristics (natural-identity), performing patriotism by speaking Malay and singing the national anthem (institution-identity), having awareness of refugees being positioned as outsiders and victims (discourseidentity), and assimilating to the local culture and communities (affinity-identity). These findings illustrate how larger societal pressures influence the socialconstructionist perspective that identity and belonging are constantly moving in the social space as the Self moves through the process of becoming and being 
as well as simultaneous "identification and disidentification" with a multitude of available identities (Kumsa 2006) that often overlap and sometimes contradict each other. An important question to ask is, "What constitutes a refugee in the Malaysian context?" When the researcher first met John, for example, she was not initially aware that he was a refugee, as he outwardly looked and spoke like an ordinary Malaysian youth. While the refugees in the studies from the West are able to fall back on their institution-identity as refugees in the third countries, second generation refugees in Malaysia are legally unable to do so. However, the analysis here has shown how the two youths navigated this in social interactions by drawing on other resources and subjectivities available to them.

Several strategies to acquire cultural capital to negotiate dual identities were mentioned in this study including using linguistic capital and social networks. As refugees, both Prince and John had no access to objectified cultural capital (material possession) and little claim to institutionalised cultural capital (credentials and status); they thus relied heavily on embodied cultural capital through linguistic capital (i.e., Malaysian accent and slang) to gain access into the local community, assimilate into Malaysian society, overtly reject being positioned as an outsider and conceal refugee identity in order to avoid hostile situations. Indeed, linguistic capital has been reported as a means to help increase social ties to local communities during migrant integration elsewhere (Nawyn et al. 2012) and is so important to the refugee community that Malay is taught in refugee schools in Malaysia (Yip 2015) despite its limited use for resettlement. This also underlines refugee uncertainty about resettlement and the strategies they have adopted to negotiate the reality that they often remain a long time in Malaysia without resettlement.

Contrary to linguistic capital (which was largely to assume only the Malaysian identity), social capital, - understood as resources or value obtained through a network of institutionalised or more informal mutual relationships (Coleman 1988) - was used to legitimise the youths' claim for both Malaysian and refugee identities. Prince retained more salient links to the Rohingya community and lived with his parents, so he had frequent access to Rohingya social networks and frequently positioned himself within the collective Rohingya identity. However, he also spoke about occasions when he preferred to assume other identities to avoid social exclusion from other groups. John preferred the company of Malaysian friends over Myanmar people, but although he did not live with his parents, his link to them helped him maintain his Burmese heritage. Close social networks have been identified in research among refugees to provide refugees with emotional and social support, but more importantly, reduce their sense of exclusion from society (Zetter and Pearl 2000; Sales 2002; Spicer 2008; Lamba and Krahn 2003). This exclusion is more acute in Malaysia as Prince framed his narratives within larger or meta-narratives found among Rohingya refugees, 
who despite having spent decades living in Malaysia, still struggle to establish a concrete sense of Self and identity due to the temporal and uncertain nature of their situation. The issue of the IC and proper legal documentation has been discussed in research among the Rohingyas as a salient issue and a source of frustration in the community (Avyanthi 2014). The lack of legal documentation translates to not just social but also economic exclusion as Rohingyas are perennially trapped in the space usually occupied by low-skilled migrant workers, who are seen as temporary and expendable (Avyanthi 2014, 843), and doing jobs that no Malaysian would want to do (Wake and Cheung 2016).

\section{IMPLICATIONS FOR POLICY}

The ease with which John and Prince were able to blend in with different local communities in Malaysia, allowed them to find some sense of belonging in their social interactions albeit temporarily. It should be noted that underlying the subjective nature of moving between identities is a current of fear and anxiety of being at risk in society, and more needs to be done to protect vulnerable refugees (especially youth) from having to lie about themselves or hide certain aspects of their identities in order to feel safe. Their reluctance to be publicly recognised as refugees is unsurprising as this comes with risk of detention and deportation. Other studies have noted that Malaysia has a history of placing refugee children in internal detention centres despite ratifying the Convention on the Rights of the Child (CRC) in 1995, and that refugee children are consistently viewed as refugees first (instead of children) (Parthiban and Khoo 2019). The lack of legislative measures and the application of general legislation on refugees (Supaat 2014) implies that as illegal immigrants, any international documents refugees possess can be arbitrarily ignored by the authorities. The push for protecting refugee children in Malaysia has largely come from humanitarian NGOs, who continually negotiate with the government over alternatives to detaining refugee children (Parthiban and Khoo 2019). However, any durable change requires initiative from the government in terms of proper legislation and implementation. One positive step forward would be for the current Pakatan Harapan government to fulfil their election manifesto promise of refugee protection (Pakatan Harapan 2018) by implementing sustainable legislation that supports and protects the refugee population in Malaysia from being viewed and managed as illegals.

The importance of linguistic capital and social networks for refugees cannot be understated. When refugees retreat into more closed and existing networks instead of bridging out into non-refugee networks (Zetter, Griffiths and Sigona 2005), they risk further discrimination from the host communities for appearing like they have no interest in integrating (Beirens et al. 2007). Malaysia could facilitate 
a better experience for refugees by allowing them more formal opportunities to access linguistic capital and local social networks. First, allowing refugee children to attend public schools with local children, and for adults to work alongside local employees, would enable refugees to gain access to social networks that increase the understanding of local communities about the plight of refugees. A recent study reported that only $30 \%$ of refugee children in the larger Kuala Lumpur area were in schools and these community schools were often poorly funded and dilapidated (Raudah et al. 2019). UNHCR data on refugee education shows that most children are only educated until 17 years old, ${ }^{3}$ leaving many stranded after they age out of advanced or secondary schooling. Without higher education opportunities or the right to work, refugee children are left to fend for themselves in search of lowskilled and often illegal work. By ignoring refugee children raised in Malaysia, the country misses out on the labour benefits and skillsets of a large group of highly trained, locally assimilated workers (Todd, Adli Amirullah and Wan 2019). Second, offering access to language classes for local languages, particular Malay, would allow refugees to acquire linguistic capital (like John and Prince) and have a sense of belonging and home.

The navigation of identity is complex and for second generation refugees, who have received little attention in research and policy (Bloch 2018), this is further complicated by the fact that some identities (i.e., being a Malaysian) are not officially available to them. But John's and Prince's narratives have shown that having the opportunity to take up dual or multiples identities go some way to helping them make sense of their liminal situation. Agencies and social workers assisting second generation refugees should be more aware of their unique liminal position and offer ways for refugees to negotiate their identity by taking up multiple ways of being, rather than viewing them through a narrow lens of being passive victims in need (Pupavac 2006; Rajaram 2002; Hoffstaedter 2017) of often merely logistical help. For young refugees struggling to establish a sense of Self, it would be helpful if they were guided through this process by being assured that the multiple subjectivities they experience are an acceptable part of doing identity work.

\section{CONCLUSION}

This article explored how two second-generation refugee youth in Malaysia struggled and coped with living as both legal and illegal in Malaysia. They mostly relied on linguistic and social capital to negotiate Malaysian and refugee identities, often switching between both or taking them up simultaneously. Thus, until more permanent legislative measures can be implemented to aid refugees, providing 
better access to linguistic and social integration is important to help refugees in transit in Malaysia feel a sense of belonging despite not being officially recognised.

\section{ACKNOWLEDGEMENTS}

I would like to thank the three anonymous reviewers for their insightful comments that allowed me to greatly improve this manuscript. This work was supported by the University of Malaya Research Grant (Grant No. RG155-12SBS).

\section{NOTES}

1. In its Global Trends 2015 report, the UNHCR reported that there was a total of 21.3 million refugees and 3.2 million asylum seekers globally but only 107,100 were accepted for resettlement and a further 201,400 returned voluntarily to their countries of origin (UNHCR 2015).

2. See for example: "Bangladesh pushes back Rohingya refugees amid collective punishment in Myanmar", Amnesty International, 24 November 2016, https://www. amnesty.org/en/latest/news/2016/11/bangladesh-pushes-back-rohingya-refugeesamid-collective-punishment-in-myanmar/ (accessed 6 September 2018).

3. Source: UNHCR (n.d.) Education in Malaysia. https://www.unher.org/en-my/ education-in-malaysia.html (accessed 6 September 2018). 


\section{APPENDIX}

\section{Transcription Convention}

(.) A dot enclosed in brackets indicates a pause in the talk of less than two-tenths of a second.

... Three dots in a row indicates a pause in the talk in tenths of a second.

$=\quad$ "Equals" sign indicates "latching" between utterances or when an interlocutor's utterances latches on to the previous interlocutor without a break.

- $\quad$ A dash indicates the sharp cut-off of the prior sound or word.

[ ] Square brackets between adjacent lines of concurrent speech indicate the onset and end of a spate of overlapping talk.

(( )) A description enclosed in a double bracket indicates a non-verbal activity.

(inaudible) Brackets provide clarification, also including brief translation of nonEnglish words or phrases.

Underlined Underlined fragments indicate speaker emphasis.

CAPITALS Words in capitals mark a section of speech noticeably louder than that surrounding it.

$<>\quad$ "Less than" and "More than" signs indicate that the talk they encompass was produced noticeable slower than the surrounding talk.

Note: Adapted from the transcription convention originally developed by Jefferson (2004). 


\section{REFERENCES}

Aberman, T. 2014. Gendered perspectives on refugee determination in Canada. Refuge 30(2): 57-65. https://doi.org/10.25071/1920-7336.39619

Brahmbhatt, K., G. Atfield, H. Irving, J. Lee and T. O’Toole. 2007. Refugees' experiences of integration: Policy related findings on employment, ESOL and vocational training. London: Refugee Council/University of Birmingham.

Atkinson, P. and S. Delamont. 2006. Rescuing narrative from qualitative research. Narrative Inquiry 16(1): 173-181. https://doi.org/10.1075/ni.16.1.23blo

Avyanthi Azis. 2014. Urban refugees in a graduated sovereignty: The experiences of the stateless Rohingya in the Klang Valley. Citizenship Studies 18(8): 839-854. https://doi.org/10.1080/13621025.2014.964546

Bailey, L. and G. İnanç. 2018. Access to higher education: Refugees'stories from Malaysia. 1st ed. London: Routledge. https://doi.org/10.4324/9781351024662

Bakhtin, M.M. 1981. The dialogic imagination: Four essays. Austin and London: University of Texas Press.

Bamberg, M. 1997. Positioning between structure and performance. Journal of Narrative and Life History 7(1-4): 335-342. https://doi.org/10.1075/jnlh.7.42pos

. 2003. Positioning with Davie Hogan: Stories, tellings, and identities. In Narrative analysis: Studying the development of individuals in society, eds. C. Daiute and C. Lightfoot, 135-157. London: Sage.

2004a. 'I know it may sound mean to say this, but we couldn't really care less about her anyway': Form and functions of 'slut bashing' in male identity constructions in 15-year-olds. Human Development 47(6): 331-353. https://doi. org/10.1159/000081036

2004b. Narrative discourse and identities. In Narratology beyond literary criticism, eds. J.C. Meister, T. Kindt, W. Schernus and M. Stein, 213-237. Berlin \& New York: Walter de Gruyter.

Beirens, H., N. Hughes, R. Hek and N. Spicer. 2007. Preventing social exclusion of refugee and asylum seeking children: Building new networks. Social Policy and Society 6(2): 219-229. https://doi.org/10.1017/S1474746406003484

Bloch, A. 2018. Talking about the past, locating it in the present: The second generation from refugee backgrounds making sense of their parents' narratives, narrative gaps and silences. Journal of Refugee Studies 31(4): 647-663. https://doi. org/10.1093/jrs/fey007

Bloch, A., M. Chimienti, A-L. Counilh, S. Hirsch, G. Tattolo, L. Ossipow and C.W. de Wenden. 2015. The children of refugees in Europe: Aspirations, social and economic lives, identity and transnational linkages. Geneva: Centre de recherches sociales (CERES).

Bloch, A. and S. Hirsch. 2017. "Second generation" refugees and multilingualism: Identity, race and language transmission. Ethnic and Racial Studies 40(14): 2444-2462. https://doi.org/10.1080/01419870.2016.1252461

Bourdieu, P. 1986. The forms of capital. In Handbook of theory and research for the sociology of education, ed. J.G. Richardson, 241-258. New York: Greenwood Press. 
. 2004. The forms of capital. In Reader in sociology of education, ed. S. Ball, 1529. London: Routledge Falmer.

Chatty, D. 2007. Researching refugee youth in the Middle East: Reflections on the importance of comparative research. Journal of Refugee Studies 20(2): 265-280. https://doi.org/10.1093/jrs/fem005

Coleman, J.S. 1988. Social capital in the creation of human capital. American Journal of Sociology 94 (Supplement: Organizations and institutions: Sociological and economic approaches to the analysis of social structure): S95-S120. https://doi. org/10.1086/228943

Crisp, J., N. Obi and L. Umlas. 2012. But when will our turn come? A review of the implementation of UNHCR's urban refugee policy in Malaysia. Geneva: UNHCR.

De Fina, A. 2008. Who tells which story and why? Micro and macro contexts in narrative. Text \& Talk 28(3): 421-442. https://doi.org/10.1515/TEXT.2008.020

2011. Researcher and informant roles in narrative interactions: Constructions of belonging and foreign-ness. Language in Society 40: 27-38. https://doi. org/10.1017/S0047404510000862

FIDH-SUARAM. 2008. Undocumentedmigrants andrefugees in Malaysia: Raids, detention and discrimination. https://www.fidh.org/IMG/pdf/MalaisieCONJ489eng.pdf (accessed 10 November 2018).

Fuglerud, O. 1997. Ambivalent incorporation: Norwegian policy towards Tamil asylumseekers from Sri Lanka. Journal of Refugee Studies 10(4): 443-461. https://doi. org/10.1093/jrs/10.4.443

Gass, A. 2014. Becoming the 'refugee': Creation of a gendered subjectivity among male asylum seekers in Switzerland. Tijdschrift voor Genderstudies 17(2): 115-129. https://doi.org/10.5117/TVGEND2014.2.GASS

Gee, J.P. 2001. Identity as an analytic lens for research in education. Review of Research in Education 25: 99-125. https://doi.org/10.2307/1167322

Hage, G. 1997. At home in the entrails of the West: Multiculturalism, 'ethnic food' and migrant home building. In Home/world space, community and marginality in Sydney's West, eds. H. Grace, G. Hage, L. Johnson, J. Langsworth and M. Symonds. Western Sydney: Pluto Press.

Hatoss, A. 2012. Where are you from? Identity construction and experiences of 'othering' in the narratives of Sudanese refugee-background Australians. Discourse \& Society 23(1): 47-68. https://doi.org/10.1177/0957926511419925

Hernandez, B., M.C. Hidalgo, M.E. Salazar-Laplace and S. Hess. 2007. Place attachment and place identity in natives and non-natives. Journal of Environmental Psychology 27(4): 310-319. https://doi.org/10.1016/j.jenvp.2007.06.003

Hirsch, S. 2019. Racism, 'second generation' refugees and the asylum system. Identities: Global Studies in Culture and Power 26(1): 88-106. https://doi.org/10.1080/107 0289X.2017.1361263

Hoffstaedter, G. 2017. Dominant discourses of refugees, recognition, and othering in Malaysia. Situations: Cultural Studies in the Asian Context 10(2): 27-44.

Human Rights Watch. 2018. Malaysia: Events of 2017. https://www.hrw.org/worldreport/2018/country-chapters/malaysia (accessed 29 April 2019). 
.2019. Malaysia: Events of 2018. https://www.hrw.org/world-report/2019/countrychapters/malaysia (accessed 29 April 2019).

Ignatieff, M. 2001. Human rights as politics and idolatry. Princeton: Princeton University Press. https://doi.org/10.1515/9781400842841

Imtiaz Ahmed. 2009. The Rohingyas: From stateless to refugee. Dhaka, Bangladesh: University of Dhaka.

Jefferson, G. 1984. Transcript notation. In Structures of social action: Studies in conversation analysis, eds. J.M. Atkinson and J. Heritage. Cambridge: Cambridge University Press.

2004. Glossary of transcript symbols with an introduction. In Conversation analysis: Studies from the first generation, ed. G.H. Lerner, 13-31. Amsterdam: John Benjamins. https://doi.org/10.1075/pbns.125.02jef

Jodeyr, S. 2003. Where do I belong? The experience of second generation Iranian immigrants and refugees. Psychodynamic Practice 9(2): 205-214. https://doi. org/10.1080/1353333031000104820

Johnson, H.L. 2011. Click to donate: Visual images, constructing victims and imagining the female refugee. Third World Quarterly 32(6): 1015-1037. https://doi.org/10. 1080/01436597.2011.586235

Kaur, A. 2007. Refugees and refugee policy in Malaysia. UNEAC Asia Papers 18(1): 7790.

Korobov, N. and M. Bamberg. 2007. "Strip poker! They don't show nothing!” Positioning identities in adolescent male talk about a television game show. In Selves and identities in narrative and discourse, eds. M. Bamberg, A. De Fina and D. Schiffrin, 253-271. Amsterdam: John Benjamins. https://doi.org/10.1075/ sin.9.12kor

Kraus, W. 2006. The narrative negotiation of identity and belonging. Narrative Inquiry 16(1): 103-111. https://doi.org/10.1075/ni.16.1.14kra

Kumsa, M.K. 2006. 'No! I'm not a refugee!' The poetics of be-longing among young Oromos in Toronto. Journal of Refugee Studies 19(2): 230-255. https://doi. org/10.1093/jrs/fel001

Labov, W. 2010. Narratives of personal experience. In Cambridge encyclopaedia of the language sciences, ed. P.C. Hogan, 546-548. Cambridge: Cambridge University Press.

Lacroix, M. 2004. Canadian refugee policy and the social construction of the refugee claimant subjectivity: Understanding refugeeness. Journal of Refugee Studies 17(2): 147-166. doi: 10.1093/jrs/17.2.147. https://doi.org/10.1093/jrs/17.2.147

Lamba, N.K. and H. Krahn. 2003. Social capital and refugee resettlement: The social networks of refugees in Canada. Journal of International Migration and Integration 4(3): 335-360. https://doi.org/10.1007/s12134-003-1025-Z

Malkki, L.H. 1995. Purity and exile: Violence, memory, and national cosmology among Hutu refugees in Tanzania. Chicago: University of Chicago Press. https://doi. org/10.7208/chicago/9780226190969.001.0001 1996. Speechless emissaries: Refugees, humanitarianism, and dehistoricization. Cultural Anthropology 11 (3): 377-404. https://doi.org/10.1525/ can.1996.11.3.02a00050 
Nawyn, S.J., L. Gjokaj, D.L. Agbényiga and B. Grace. 2012. Linguistic isolation, social capital, and immigrant belonging. Journal of Contemporary Ethnography 41(3): 255-282. https://doi.org/10.1177/0891241611433623

Pakatan Harapan. 2018. Buku harapan: Rebuilding our nation, fulfilling our hopes. http:// kempen.s3.amazonaws.com/manifesto/Manifesto_text/Manifesto_PH_EN.pdf (accessed 25 October 2018).

Parthiban, S. and Y.H. Khoo. 2019. Detention of refugee children in Malaysia and Thailand. Journal of Southeast Asian Human Rights 3(1): 59-80. https://doi.org/10.19184/ jseahr.v3i1.10142

Phan, L.H., J. Kho and B. Chng. 2013. Nation building, English as an international language, medium of instruction, and language debate: Malaysia and possible ways forward. Journal of International and Comparative Education 2(2): 58-71.

Pieloch, K., M.B. McCullough and A.K. Marks. 2016. Resilience of children with refugee statuses: A research review. Canadian Psychology 57(4): 330-339. https://doi. org/10.1037/cap0000073

Portes, A. and D. MacLeod. 1996. Educational progress of children of immigrants: The roles of class, ethnicity, and school context. Sociology of Education 69(4): 255275. https://doi.org/10.2307/2112714

Portes, A. and M. Zhou. 1993. The new second generation: Segmented assimilation and its variants. Annals of the American Academy of Political and Social Science 530: 74-96. https://doi.org/10.1177/0002716293530001006

Pupavac, V. 2006. Refugees in the 'sick role': Stereotyping refugees and eroding refugee rights. In New issues in refugee research. Geneva: UNHCR.

Pūras, D. 2015. Report of the special rapporteur on the right of everyone to the enjoyment of the highest attainable standard of physical and mental health. Geneva: United Nations General Assembly.

Rajaram, P.K. 2002. Humanitarianism and representations of the refugee. Journal of Refugee Studies 15(3): 247-264. https://doi.org/10.1093/jrs/15.3.247

Raudah Mohd Yunus, Nur Aisyah Zainordin, Nur Saniah Shamsuddin, Nur Athira Zailana and Nur Sabila Syazwani Hariyono. 2019. 70 per cent of refugee kids do not go to school. New Straits Times, 4 August. https://www.nst.com.my/opinion/ letters/2019/08/510066/70-cent-refugee-kids-do-not-go-school.

Riessman, C.K. 2005. Narrative analysis. In Narrative, memory \& everyday life, 1-7. Huddersfield: University of Huddersfield.

Rumbaut, R.G. 2004. Ages, life stages, and generational cohorts: Decomposing the immigrant first and second generations in the United States. International Migration Review 38(3): 1160-1205. https://doi.org/10.1111/j.1747-7379.2004. tb00232.x

2012. Generation 1.5, educational experiences of. In Encyclopaedia of diversity in education, ed. J.A. Banks, 982-983. Thousand Oaks, CA: Sage Publications.

Sacks, H., E.A. Schegloff and G. Jefferson. 1974. A simplest systematics of the organization of turn-taking for conversation. Language in Society 50: 696-735. https://doi. org/10.1353/lan.1974.0010 
Sales, R. 2002. The deserving and undeserving? Refugees, asylum-seekers and welfare in Britain. Critical Social Policy 22(3): 456-478. https://doi. org/10.1177/026101830202200305

Sirriyeh, A. 2010. Home journeys: Im/mobilities in young refugee and asylum-seeking women's negotiations of home. Childhood 17(2): 213-227. https://doi. org/10.1177/0907568210365667

.2013. Inhabiting borders, routes home: Youth, gender, asylum. Farnham: Ashgate.

Sorgen, A. 2015. Integration through participation: The effects of participating in an English conversation club on refugee and asylum seeker integration. Applied Linguistics Review 6(2): 241-260. https://doi.org/10.1515/applirev-2015-0012

Spicer, N. 2008. Places of exclusion and inclusion: Asylum-seeker and refugee experiences of neighbourhoods in the UK. Journal of Ethnic and Migration Studies 34(3): 491-510. https://doi.org/10.1080/13691830701880350

Spradley, J.P. 1979. Asking descriptive questions. In The ethnographic interview. New York: Holt, Rinehart and Winston.

Supaat, D.I. 2014. Refugee children under the Malaysian legal framework. UUM Journal of Legal Studies 4: 118-148.

Ting, S.H. 2016. Being Malaysian: Identifying characteristics. In Researching society and culture in Sarawak, eds. Kamsiah Ali and Sharifah Sophia Wan Ahmad, 217240. Kota Samarahan, Sarawak: Penerbit Universiti Malaysia Sarawak.

. 2017. An agenda-setting study of national day coverage in state and national newspapers. 3L: The Southeast Asian Journal of English Language Studies 23(4): 41-55. https://doi.org/10.17576/3L-2017-2304-04

Todd, L., Adli Amirullah and S.W. Ya. 2019. Economic impact of granting refugees in Malaysia the right to work. Policy paper no. 60. Kuala Lumpur: Institute for Democracy and Economic Affairs (IDEAS).

Turner, V. 1967. Betwixt and between: The liminal period in rites de passage. In The forest of symbols: Aspects of Ndembu ritual, 93-111. Ithaca: Cornell University Press.

UNESCO. 2018. Global education monitoring report 2019; Migration, displacement and education: Building bridges, not walls. Paris: UNESCO.

UNHCR Malaysia. 2015. Global trends: Forced displacement in 2015. Geneva: UNHCR. . n.d. Figures at a glance. http://www.unhcr.org.my/About_Us-@-Figures_At_A_ Glance.aspx (accessed 21 December 2016).

Valentine, G., D. Sporton and K.B. Nielsen. 2009. Identities and belonging: A study of Somali refugee and asylum seekers living in the UK and Denmark. Environment and Planning D: Society and Space 27(2): 234-250. https://doi.org/10.1068/ d3407

Wake, C. and T. Cheung. 2016. Livelihood strategies of Rohingya refugees in Malaysia: 'We want to live in dignity'. London: Humanitarian Policy Group (HPG).

Wernesjö, U. 2015. Landing in a rural village: Home and belonging from the perspectives of unaccompanied young refugees. Identities: Global Studies in Culture and Power 22(4): 451-467. https://doi.org/10.1080/1070289X.2014.962028

White, M.J. and J.E. Glick. 2000. Generation status, social capital, and the routes out of high school. Sociological Forum 15(4): 671-691. https://doi. org/10.1023/A:1007515100190 
Yip, Y.T. 2015. Volunteers go all out to teach underprivileged kids. The Star Online. 8 May. https:/www.thestar.com.my/Metro/Focus/2015/05/08/For-the-sake-oftheir-future/ (accessed 6 September 2018).

Yuval-Davis, N. 2006. Belonging and the politics of belonging. Patterns of Prejudice 40(3): 197-214. https://doi.org/10.1080/00313220600769331

. 2010. Theorizing identity: Beyond the 'us' and 'them' dichotomy. Patterns of Prejudice 44(3): 261-280. https://doi.org/10.1080/0031322X.2010.489736

. 2016. Power, intersectionality and the politics of belonging. In The Palgrave handbook of gender and development: Critical engagements in feminist theory and practice, ed. W. Harcourt, 367-381. London: Palgrave Macmillan UK. https://doi.org/10.1007/978-1-137-38273-3_25

Zetter, R., D. Griffiths and N. Sigona. 2005. Social capital or social exclusion? The impact of asylumseeker dispersal on UK refugee community organisations. Community Development Journal 40(2):169-181. https://doi.org/10.1093/cdj/bsi025

Zetter, R. and M. Pearl. 2000. The minority within the minority: Refugee communitybased organisations in the UK and the impact of restrictionism on asylumseekers. Journal of Ethnic and Migration Studies 26(4): 675-697. https://doi. org/10.1080/713680501

Zhou, M. and C.L. Bankston. 1998. Growing up American: How Vietnamese children adapt to life in the United States. New York, NY: Russell Sage Foundation.

Zuraidah Mohd Don and C. Lee. 2014. Representing immigrants as illegals, threats and victims in Malaysia: Elite voices in the media. Discourse \& Society 25(6): 687705. https://doi.org/10.1177/0957926514536837 